Стимулювання майбутніх учителів образотворчого мистецтва до знання традицій, обрядів і звичаїв народу засобами дизайн-проєктів

УДК 370

\title{
СТИМУЛЮВАННЯ МАЙБУТНІХ УЧИТЕЛІВ ОБРАЗОТВОРЧОГО МИСТЕЦТВА ДО ЗНАННЯ ТРАДИЦЙ, ОБРЯДІВ І ЗВИЧАЇВ НАРОДУ ЗАСОБАМИ ДИЗАЙН-ПРОЄКТІВ
}

\author{
Вікторія Коваленко \\ аспірантка кафедри педагогіки \\ Криворізький державний педагогічний університет \\ м. Кривий Ріг, Україна \\ ORCID ID 0000-0001-8383-2723 \\ kovalenko.vik.k@gmail.com
}

\begin{abstract}
Анотація. У статті проаналізовано забезпечення стійкої мотивації вчителів образотворчого мистецтва в застосуванні дизайн-проєктів у професійній діяльності як засобу стимулювання до знання традицій, обрядів і звичаїв українського народу. Під впливом стимулювання до традицій українського народу формується світогляд особистості, який впливає на уявлення людини не лише про навколишній світ, а й на власний внутрішній світ, на адекватну оцінку ситуації і адекватне ії сприйняття.

Дизайн-проєкт як творчий метод формування в студентів етнохудожньої культури грунтується на національних засадах традиційного декоративно-ужиткового мистецтва й сучасного дизайну, сприяє розвитку художньо-проєктної культури, творчих якостей особистості, вихованню національної самосвідомості, необхідних для здійснення ефективної професійно-педагогічної діяльності.
\end{abstract}

Ключові слова: стимулювання; традиції; дизайн; дизайн-проєкт; проєктування; етнодизайн.

Постановка проблеми в загальному вигляді. У системі освіти великого значення на сьогодні набуває проблема підготовки висококваліфікованих фахівців, серед яких важливе місце займає професіоналізм, соціальна активність та креативний підхід до виконання творчих завдань. Перехід українського суспільства на новий етап побудови демократичної держави зумовив необхідність розв'язання завдань, пов'язаних із розвитком духовної культури особистості, бо їй належить визначна роль у формуванні нової людини: освіченої, вихованої, культурної, здатної до самоосвіти, саморозвитку.

На сучасному етапі розвитку суспільства виникає проблема підвищення ефективності навчальної діяльності на всіх рівнях освіти. Під впливом стимулювання до традицій українського народу формується світогляд особистості, який впливає на уявлення людини не лише про навколишній світ, а й на власний внутрішній світ, на адекватну оцінку та сприйняття ситуації.

Аналіз останніх досліджень і публікацій. Окремі аспекти виховання молоді на національно-культурних традиціях українського народу розглядались у дослідженнях А. Бойко, Р. Дзвінки, О. Дубасенюк, П. Ігнатенко, Ю. Руденко, М. Стельмаховича, В. Струманського, В. Попружного, Г. Шевченка.

Професіоналізм педагога: теоретичні й методичні аспекти. - Вип. 11. - Слов’янськ, 2019. 
Стимулювання майбутніх учителів образотворчого мистецтва до знання традицій, обрядів і звичаїв народу засобами дизайн-проєктів

У дослідженнях А. Афанасьєва, М. Бахтіна, П. Богатирьова, В. Гусєва, М. Громико, В. Проппа та інших розкриті особливості народно-художньої свідомості, які проявляється в народній культурі та в естетично спеціалізованих традиційних формах художньо-творчої діяльності. Проблемі етнодизайну та різноманітним технікам художньої обробки текстильних матеріалів присвячено чимало праць сучасних авторів та вчених-педагогів: Л. Оршанський, Н. Кузан, С. Кучер, Ю. Кулінка, Л. Савка, Н. Дубова, Т. Андріанова, О. Макарова, 3. Котенкова, Р. Андрієва та ін.

Формулювання цілей статті. Мета статті - проаналізувати забезпечення стійкої мотивації вчителів образотворчого мистецтва в застосуванні дизайнпроєктів у професійній діяльності як засобу стимулювання до знання традицій, обрядів і звичаїв українського народу. Задачі: 1) уточнення понять: «дизайн», «дизайн-проєкт»; 2) розгляд етапів створення дизайн-проєкту; 3) проведення анкетування 3 метою визначення методів стимулювання студентів над завданнями дизайн-проєкту.

Методика дослідження полягає в тому, що було використано метод анкетування 3 метою визначення методів стимулювання роботи студентів над дизайн-проєктом на етапі констатувального експерименту. 3 метою визначення наявності діяльнісного досвіду в області знання традицій, обрядів українського народу був проведений наглядний аналіз творчих робіт студентів на дисциплінах: «Художня обробка матеріалів» та «Комп'ютерна графіка».

Виклад основного матеріалу. Дизайн синтезує духовне та матеріальне i виступає системою культурно-естетичних зв'язків. Побутові речі, знаряддя праці несуть у собі дух і суть людської культури. Отже, дизайн $є$ репрезентований вид мистецтва, який виконує роль етнічної трансляції. Як могутній засіб комунікації, він об'єднує людей у суспільні групи за законам стилю, напрямку, моди (Чирва, 2012, с. 179). Дизайн-проєкт - це розробка індивідуального стилю об'єкта проєктування. За допомогою дизайн-проєкту студент поєднує використання сучасних технологій і елементів етнічної культури, які засвоюються в процесі вивчення технік декору, художніх й технологічних особливостей виготовлення декоративно-ужиткових виробів (Радченко, 2002, с. 174).

Проведене спостереження дає підгрунтя стверджувати, що застосування дизайн-проєкту в навчальній роботі значно підвищує творчий потенціал студентів, що формується, розвиваючи не лише абстрактне, комбінаторне, асоціативне, логічне мислення, але i підвищуючи загальний коефіцієнт художньої культури. Навчання засобами дизайн-проєкту стрімко прискорює формування етнохудожньої культури, розвивається просторово-часове уявлення, формується почуття поваги до народної культури та соціальнокультурний світогляд. 
Стимулювання майбутніх учителів образотворчого мистецтва до знання традицій, обрядів і звичаїв народу засобами дизайн-проєктів

Дизайн-проєкт національного одягу, інтер'єру майстерні, кабінету в народному стилі формує смак, учить цінувати і сприймати красиве і сприяє вихованню бажання створювати навколо себе красиві речі. Уміле поєднання в проєкті предметів декоративно-ужиткового мистецтва: художніх виробів із дерева, керамічних виробів, вишитих рушників, серветок, декоративних панно сприяє глибокому й естетичному прилученню студентів до етнічної культури, впливає на розвиток художнього смаку, збагачує духовний світ. Яскравим прикладом створення дизайн-проєкту є проєктування національного одягу.

Процес створення в дизайні одягу - це пошук єдності форми і змісту. При вирішення творчих завдань використання традиційних методів проєктування $\epsilon$ незавжди можливим. Тому важлива активізація творчого пошуку в проєктуванні, яка направлена на розвиток творчого проєктного мислення дизайнера i на інтенсифікацію самого процесу проєктування (Баран, 2007, с. 215). Під час проєктування нових форм одягу використовують різні художні образи (джерела творчості). 3 реальної дійсності, що супроводжує людину, можна мати майже все, що якимось чином можливо трансформувати, перевтілити в костюм: чи то мотив, чи то фрагмент будь-чого, чи то першоджерело загалом. Власне, етнодизайн існував завжди, адже творча діяльність народних майстрів i професійних художників несе в собі національні риси, менталітет та естетичні вподобання народу. Тому нині існує стійка зацікавленість тими видами прикладного мистецтва, які спрямовані на створення досконалих естетичних i практичних властивостей об'єктів матеріального середовища. Сучасний досвід створення модного вбрання демонструє - незалежно від напряму моди, тобто від того, у якому руслі відбувається формування сучасного одягу - традиційні риси етнодизайну, які тією чи тією мірою присутні завжди (Попова, Королёва, Чирков, 1984, с. 55).

Праця 3 національними зразками задля пошуку творчого імпульсу має неодмінно супроводжуватись прагненням проникнути до витоків народного духу, пізнати «художню душу» нації.

Ми підтримуємо думку науковців, що народний костюм у всі часи $і$ для всіх народів був і залишається постійним джерелом натхнення. Способи використання народного костюма як джерела в дизайні сучасного одягу можуть бути найрізноманітнішими: дослівне його трактування, стилізація при збереженні певних ознак подібності, використання народного крою, запозичення розміщення декору, використання старих технік оздоблення на нових матеріалах, або, навпаки, нових технік оздоблення (Баран, 2007; Чирва, 2012).

Професіоналізм педагога: теоретичні й методичні аспекти. - Вип. 11. - Слов’янськ, 2019. 
Метою дизайн-проєктів є стимулювання інтересів студентів до окремих проблем, що передбачають оволодіння ними певною сумою знань, та через проєктну діяльність, яка включає практичне застосування самостійно набутих знань у процесі вирішення практичних завдань і проблем.

Робота над дизайн-проєктом складається 3 трьох основних етапів: планувальний етап (зняття замірів наявної конфігурації стін; вивчення особливостей об'єкта проєктування; зонування; розробка планувальних рішень), стильовий етап (об’ємне моделювання; розробка об'ємно-графічних і кольорово-фактурних варіантів художнього рішення), технологічний етап (розробка плану, виконання ескізних креслень конструкцій, технологічна послідовність).

Визначимо основні вимоги до використання дизайн-проєктів: формулювання значущої проблеми (задачі) в планувальному етапі, яка вимагає для інтегрованого знання дослідницького пошуку; практична, теоретична, пізнавальна значущість передбачених результатів; самостійна діяльність студентів; застосування інформаційно-комунікативних технологій.

Дизайн-проєкт у діяльності майбутніх учителів здатен перетворити навчання в почуттєво-захоплюючий процес, зробити його посильним для кожного студента, у кінцевому результаті їхня навчальна діяльність переростає у творчість, сприяє поступовому розкриттю художніх здібностей і талантів (Дубровский, 1996, с. 38).

Результати дослідження. Було проведено анкетування 3 метою визначення застосування методів стимулювання в проведені занять над дизайнпроєктом. Отримані результати констатувального експерименту відображені в діаграмі.

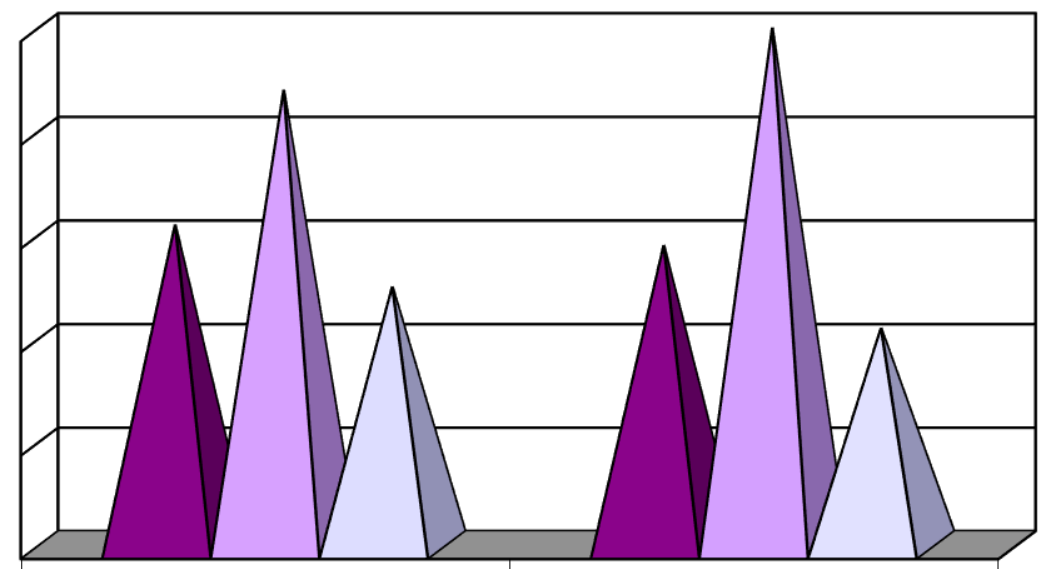

\section{口 Високий \\ 口Середній \\ 口Низький}

Контрольна група

Експериментальна група

Аналізуючи результати анкетування, можна сказати, що емоційний стан 
Стимулювання майбутніх учителів образотворчого мистецтва до знання традицій, обрядів і звичаїв народу засобами дизайн-проєктів

щодо стимулювання студентів при виконані дизайн-проєкту в групах дещо відрізняється. Деякі студенти не можуть охарактеризувати поняття «дизайнпроєкт», «народний етнос» і не мають наміру поглиблювати свої знання. Було видно, що студенти мають бажання вивчати дисципліну «Комп’ютерна графіка», і тому були зауваження, що на вивчення дисципліни надано мало годин.

Але загалом результати анкетування доводять необхідність підвищення стимулювання студентів до вивчення та формування в них бажання вивчати народні (етнічні) традиції та культуру. Отже, саме 3 цією метою варто використовувати дизайн-проєктування, які позитивно вплинуть і на пізнавальну активність, і на вивчення народних традицій на відміну від традиційних методів навчання.

3 метою визначення наявності діяльнісного досвіду в області знання традицій, обрядів українського народу був проведених наглядний аналіз творчих робіт студентів на дисциплінах: «Художня обробка матеріалів» та «Комп’ютерна графіка».

Отримані результати констатувального експерименту відображені в діаграмі.

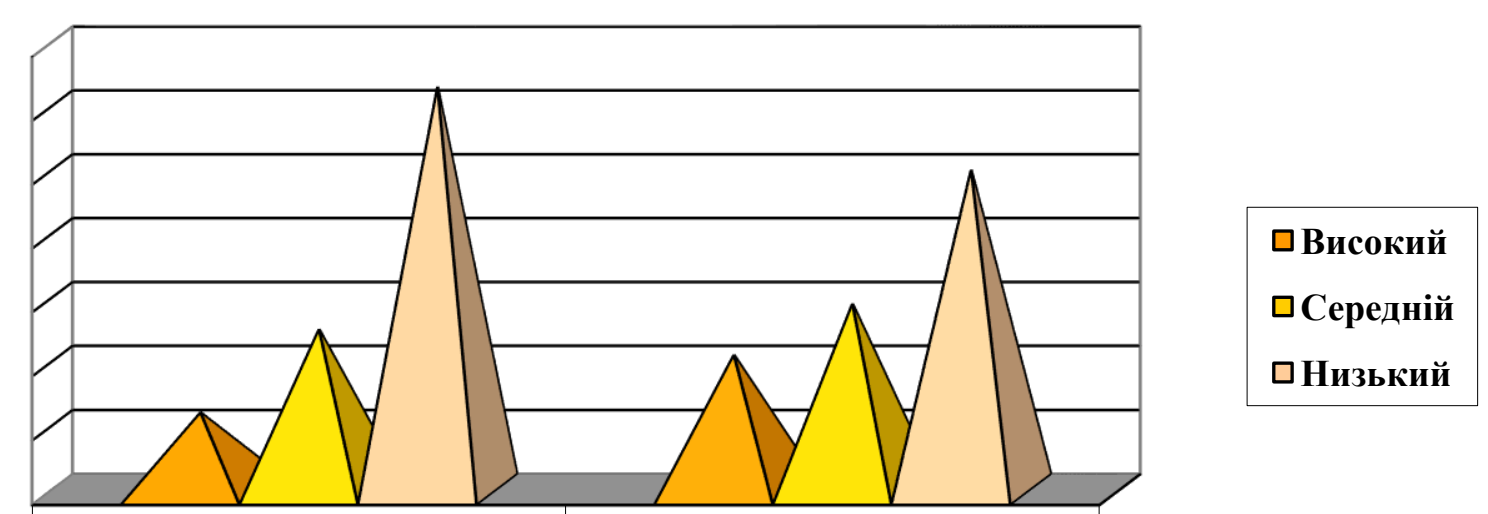

Контрольна група

Експериментальна група

Загалом за результатами аналізу творчих робіт студентів можна зробити висновок, що студенти, не зовсім зацікавлені культурою свого народу. Це видно 3 творчих робіт студентів, які не відображають етнодизайн.

Нами була розроблена програма спецкурсу «Етнодизайн засобами комп'ютерної графіки», яка сприятиме стимулюванню в студентів бажання займатися та вивчати народні традиції українського народу.

Метою нашого дизайн-проєкту є створення сучасного етнічного костюма 3 використанням традиційних національних елементів за допомогою графічного редактору Adobe Photoshop. Тобто за допомогою програми зробити модельний 
Стимулювання майбутніх учителів образотворчого мистецтва до знання традицій, обрядів і звичаїв народу засобами дизайн-проєктів

ряд етнічного костюма, у якому б відображалися елементи традиційного національного одягу з використання сучасного крою, тканин та оздоблення.

Adobe Photoshop - це професійний растровий дизайнерський редактор. Основним призначенням програми $є$ створення фотореалістичних зображень, ретушування, вебдизайн, колірна корекція, створення колажів, а також вебдизайн і електронні публікації.

Так, використання дизайн-проєктів у вищій школі надає можливість викладачеві стимулювати студентів до знання традицій, обрядів і звичаїв свого народу, спонукати до самостійної роботи (індивідуальної, парної, групової), підбирати теми проєктів, що максимально цікавлять студентів тощо. А його використання в процесі вивчення дисципліни «Комп’ютерна графіка» у вищому навчальному закладі:

- розширює й урізноманітнює програму вивчення дисципліни «Комп’ютерна графіка»;

- сприяє значно швидшому формуванню етнохудожньої культури студентів;

- активізує дослідницьку та творчу діяльність студентів на всіх етапах навчання;

- формує вміння обирати необхідну інформацію;

- розширює кругозір студента;

- дозволяє творчо підходити до виконання роботи;

- формує професійні педагогічні вміння та навички (Полат, 2007, с. 80).

У дизайн-проєктній роботі студенти залучаються до пошукової, дизайнерської діяльності. Використання дизайн-проєкту робить можливим формування та розвиток пошуково-дослідницьких, комунікативних, технологічних, інформаційних компетенцій, формує креативність, стимулює інтелектуальну активність, розвиває комунікативні вміння, допомагає формувати міжпредметні зв'язки, учить використовувати інформаційнотелекомунікаційні технології у вивченні етнохудожньої культури.

Крім того, усе це підвищує мотивацію студентів, бо в цьому випадку дизайн-проєкт стає не ціллю, а засобом формування художньої культури майбутніх учителів. Навіть найслабші студенти можуть креативно проявити себе в повній мірі, виконуючи дизайн-проєкт 3 елементами етнокультури свого народу.

Отже, здійснювати дизайнерське проєктування $є$ необхідною педагогічною умовою фахової підготовки майбутніх учителів образотворчого мистецтва та формування в них народної культури. 
Стимулювання майбутніх учителів образотворчого мистецтва до знання традицій, обрядів і звичаїв народу засобами дизайн-проєктів

\title{
Висновок $з$ дослідження і перспективи подальших розвідок у цьому
} напрямі. Дизайн-проєкт як творчий метод формування в студентів етнохудожньої культури грунтується на національних засадах традиційного декоративно-ужиткового мистецтва й сучасного дизайну, сприяє розвитку художньо-проєктної культури, творчих якостей особистості, вихованню національної самосвідомості, необхідних для здійснення ефективної професійно-педагогічної діяльності. Дизайн дає надзвичайну свободу для творчих пошуків при виконанні дизайн-проєкту, бо грунтується на синтезі архаїчного, аутентичного, етнічного матеріалу й сучасних академічних i неакадемічних форм культури. Подальшу роботу вбачаємо в розробці критеріїв з оцінювання дизайн-проєкту.

\section{СПИСОК ВИКОРИСТАНИХ ДЖЕРЕЛ}

1. Баран, В. (2007). Етногенез украӥнського народу: короткий нарис. Київ, Украӥна: Товариство «Знання».

2. Дубровский, Е. Н. (1996). Информационно-обменные проиессы - факторы соииального развития. Москва, Российская Федерация: Союз.

3. Попова, О. С., Королёва, Н. С. і Чирков, Д. А. (1984). Народные художественные промыссльг. Москва, Российская Федерация: Легкая и пищевая пром-сть.

4. Полат, Е. С. (2007). Новые педагогические и информационные технологии в системе образования. Москва, Российская Федерация: Академия.

5. Радченко, К. В. (2002). Дизайн: історія і сучасність. Україна: Шкільна бібліотека.

6. Савченко, Л. О. (2011). Проектні технології як засіб підвищення якості знань студентів вищої педагогічної школи. Наукові записки Тернопільського національного педагогічного університету імені Володимира Гнатюка. Педагогіка, 3. (С. 362-366). Тернопіль, Україна.

7. Чирва, О. (2012). Етноскладова дизайн - освіти. Становлення $i$ розвиток етнодизайну: украйнський та європейський досвід: Матеріали I Міжнародної науковопрактичної конференції. (С. 174-179). Полтава, Україна: Полтавський літератор.

8. Ягупов, В. В. (2002). Педагогіка. Київ, Україна: Либідь.

\section{FUTURE ART TEACHER STIMULATING TO LEARN FOLK TRADITIONS AND CEREMONIES BY MEANS OF DESIGN-PROJECTS}

\author{
Victoriia Kovalenko \\ PhD student of Department of Pedagogy \\ Kryvyi Rih State Pedagogical University, \\ Kryvyi Rih, Ukraine \\ ORCID ID 0000-0001-8383-2723 \\ kovalenko.vik.k@gmail.com
}

\begin{abstract}
The article analyzes providing sustainable motivation of fine arts teachers to implement design projects in their professional activity as a means of stimulating the knowledge of traditions, rituals and customs of the Ukrainian people. Under the influence of stimulation to learn
\end{abstract}

Професіоналізм педагога: теоретичні й методичні аспекти. - Вип. 11. - Слов'янськ, 2019. 


\section{В. КОВАЛЕНКО}

Стимулювання майбутніх учителів образотворчого мистецтва до знання традицій, обрядів і звичаїв народу засобами дизайн-проєктів

the traditions of the Ukrainian people, the world outlook of an individual is formed, which influences not only the person's notion of the surrounding world, but also his or her own inner world, an adequate assessment of the situation and its adequate perception.

Design-project as a creative method of formation of students of ethno-artistic culture is based on national principles of traditional decorative and applied art and modern design, contributes to the development of art-project culture, creative qualities of personality, education of national consciousness, necessary for the effective professional and pedagogical activity. Thus, the use of design projects in high education institutions allows the teacher to stimulate students to learn the traditions, rituals and customs of their people, to encourage independent work (individual, paired, group), to select topics of projects that are most interesting for students, etc. The paper presents the use of design projects in the study of Computer Graphics in higher education institutions. The design gives tremendous freedom for creative pursuits in the design project, as it is based on the synthesis of archaic, authentic, ethnic material and contemporary academic and non-academic forms of culture.

Key words: stimulation; traditions; design; design project; ethno-design.

\section{REFERENCES} Znannia.

1. Baran, V. (2007). Ethnogenesis of the Ukrainian people [brief sketch]. Kyiv, Ukraine:

2. Dubrovskiy, E. N. (1996). Information-exchange processes-factors of social development. Moscow, the Russian Federation: Soyuz.

3. Popova, O. S., Koroleva, N. S. \& Chirkov, D. A. (1984). Folk art crafts. Moscow, the Russian Federation: Legkaya i pishchevaya promyshlennost.

4. Polat, E. S. (2007). New pedagogical and information technologies in the educational system. Moscow, the Russian Federation: Academy.

5. Radchenko, K. V. (2002). Design: History and Modernity. Ukraine: Shkilna Biblioteka.

6. Savchenko, L. O. (2011). Design technologies as a means of improving the quality of knowledge of students of higher pedagogical school. Scientific notes of the Ternopil National Pedagogical University named after Vladimir Hnatyuk. Pedagogy, 3, 362-366.

7. Chyrva, O. (2012). Ethno-component design - education. Formation and development of ethno-design: Ukrainian and European experience: Proceedings of the 1st International Scientific and Practical Conference. (pp. 174-179). Poltava, Ukraine.

8. Yahupov, V. V. (2002). Pedagogy. Kyiv, Ukraine: Lybid.

\section{Матеріали надійшли до редакції 30.10.2019 p.}

